Pre print version. To cite this article: Franco Zappettini \& Michał Krzyżanowski (2019): The critical juncture of Brexit in media \& political discourses: from national-populist imaginary to cross-national social and political crisis, Critical Discourse Studies, DOI: 10.1080/17405904.2019.1592767

To link to this article: https://doi.org/10.1080/17405904.2019.1592767

\title{
The critical juncture of Brexit in media \& political discourses: from national-populist imaginary to cross-national social and political crisis
}

\author{
Franco Zappettinia and Michał Krzyżanowskib,c \\ ${ }^{a}$ Department of Communication and Media, School of the Arts, University of Liverpool, Liverpool, UK; bSchool \\ of Humanities, Education \& Social Science, Örebro University, Örebro, Sweden; 'Department of \\ Communication and Media, School of the Arts, University of Liverpool, Liverpool, UK
}

KEYWORDS Brexit; critical juncture; crisis; critical discourse analysis; mediatisation; politicisation

\section{Introduction}

While the exact nature of Britain's exit from the EU - or 'Brexit' as it has been popularised - is still as unclear as whether it will take place at all, the complex ontology, unfolding and impact of such an unprecedented event have been investigated widely in several aca- demic fields and especially in the sizeable body of work at the intersection of sociological, political and communicative dimensions (see for example, Clarke \& Newman, 2017; Evans \& Menon, 2017; Koller, Kopf, \& Miglbauer, 2019; Ridge-Newman, Leon-Solis, \& O'Donnell, 2018; Outhwaite, 2017; Wincott, Peterson, \& Convery, 2017).

While our special issue joins the existent studies, it also differs from such work by specifically taking a critical discursive perspective. In doing so, we rely on an interpretation of Brexit as a 'critical juncture' (see below) in which different historical and contingent discursive nexuses and trajectories have been at play. Hence, we focus on the interplay between socio-political contexts as well as, therein, on various patterns of discursive work of both mediatisation and politicisation of Brexit, both before and after the UK 2016 EU Referendum. Through our focus, we explore a variety of context-dependent, ideologicallydriven social, political and econ- omic imaginaries that were attached to the idea/concept of Brexit and related notions in the process of their discursive articulation and legitimation in the UK and internationally.

Our contribution has thus three interrelated aims. First, the articles in this special issue provide evidence of how the Brexit referendum debate and its immediate reactions were discursively framed and made sense of by a variety of social and political actors and through different media. Second, we show how 
such discourses reflect the wider path-dependent historical and political processes which have been instrumental in defining the discursive and mediatic contexts within which Brexit has been articulated. Third, we identify discursive trajectories at play in the ongoing process of Brexit putting forward an agenda for further analysis of such trajectories.

\section{The critical juncture of Brexit}

The notion of critical juncture is well established in political studies and institutional theory and refers to 'situations of uncertainty in which decisions of important actors are causally decisive for the selection of one path of institutional development over other possible paths' (Capoccia, 2016; see also Zappettini, 2019b). In this sense, junctures are regarded as 'critical' because they set in motion path-dependent processes - in other words self- reinforcing trajectories - that become difficult to reverse as they eventually consolidate into one specific dominant institutional setup. At the same time, in a critical juncture, the contingent context in which choices are debated and made can also be seen as the result of institutional, cultural, and political trajectories which are reliant on antecedent conditions.

But nominally and more widely, the notion of critical juncture also corresponds to the idea that connects 'critique and crisis' (Koselleck, 1979; Krzyżanowski, 2019) pointing to the fact that - whether imagined or real - critical moments of history entail acceleration of discursive articulations of various visions of social reality as well as of their ideological foundation and legitimation. At such phases of a critical juncture, collective 'scope of experience' and 'horizon of expectations' (Koselleck, 2004) coagulate into various visions of collective past and future that give rise to patterns of understanding of the new, emergent social status quo. Rather than emerging as a discrete event, therefore, a critical juncture is more likely to consist of an accumulation of related events leading to a rapid social, political and institutional change. Of course, such events are ultimately driven by human agents, their ideologies, their interests and by the discourses through which specific choices are advocated and deliberation over such choices are made.

Drawing on the above, in this special issue we hence approach Brexit as a critical juncture 'in the making'. We see Brexit emerging at the intersection of different path-dependent discursive trajectories which have accumulated 'forces, antagonisms and contradictions' (Clarke \& Newman, 2017, p. 102) over a period of time and have resulted in the contingency of the 2016 referendum in which British voters were asked to decide whether to leave or remain in the European Union. To paraphrase Capoccia and Kelemen (2007) who - taking up Berlin (1974) - define contingency as 'the study of what happened in the context of what could have happened' ( $p$. 355), this special issue hence examines discourses of Brexit as 'what was said in the context of what could have been said'. Our interest thus is not in language use per $s e$, but rather in discursive practices as vehicles of different attitudes and ideologies. We therefore appeal to dis- courses as wider perspectives and as specific entry points for the analysis. They help us explore how some of the linguistic and semiotic productions surrounding the contingency of the Brexit referendum relate to different path-dependent trajectories and how these discourses have been articulated and 
seized upon by different actors at the time of the said critical juncture. For example, in its contingent form, Brexit has been a process defined by political opportunism aimed at reigning in the infight over Europe inside the Conservative Party but, in turn, such process have been fuelled by long-standing trajectories of British imperialism and Euroscepticism rooted in the historical visions of the relationship between Britain and the 'continent' and in the perceived distinct history of the British Empire and its democratic traditions from wider Europe (see, in particular, Maccaferri, 2019).

The contingency of the 2016 Referendum on Brexit has also involved the (re)articulation of social, political and cultural narratives along logics of rupture, continuity or, in some cases, contradictorily both (Zappettini, 2019a). At institutional level, for example, dis- courses of 'one United Kingdom' which downplayed or even silenced the gamut of different regional views of Brexit across England, Scotland, Wales, and Northern Ireland were contrasted by narratives of rupture with the EU as an institutional framework politi- cally and economically incompatible with Britain and its trade ambitions. At the same time, however, the institutional rhetoric has also portrayed new 'global' Britain as committed to 'shared European values' as the UK 'leaves the EU but not Europe' (see Krzyżanowski, 2010 for the ambivalent discursive constructions of the EU and Europe) and as the government vision for an out-ofthe-EU UK has gradually shifted from 'ambitious' to 'pragmatic'.

The Brexit referendum was also - or perhaps in particular - reasserted and articulated through a discursive contingency based on the simplistic antagonism of the in/out binaries. These binaries were discursively appropriated by different actors and, in turn, they indexed larger ideological struggles over key political and social issues. For example, Brexit has been interpreted in relation to an international surge in populist backlash against globalisation and Europeanization as the perceived causes of rapid social changes (Calhoun, 2017). In this sense, for many 'Leavers', Brexit embodied the perceived opportunity for Britain to shift away from an 'unavoidable' supranational path inside the EU back to a 'safer' (inter)national system of relations. However, the Leave campaign 'take back control' slogan often represented a floating signifier that instrumentally legitimised both a logic of global deceleration rejecting neoliberalism and austerity (through the argument that power taken over by the EU global governance project should be reigned back into national remits) and a logic of global acceleration advocating further liberalisa- tion and international free trade (through the argument that EU regulations prevent the UK from taking full advantage of worldwide economic opportunities) (cf. Zappettini, 2019a, 2019b).

\section{Unpacking discourses of Brexit: contributions in this special issue}

The contributions to this special issue reflect the multilevel, actor-specific discursive trajectories that have characterised Brexit as a mediated critical juncture. The first article by Maccaferri (2019) sets the scene by taking a historical perspective and tracing how British political discourse has traditionally constructed the relation between the UK and the 'continent' as an uncomfortable one. Analysing a corpus of traditional and online press cover- age of the referendum, Maccaferri suggests that, 
along with interpretations of Brexit as a rejection of the élite, of austerity policies, and of globalisation, the thrust of the referendum debate was found in the recontextualisation of Eurosceptic discourses that have been circulating in British politics since the 1960s and which, in turn, are rooted in the historical idea of the British Empire. The press portrayal of this renewed belief in the nation's future, Maccaferri claims, was a significant driver of the Brexit vote as well as an expression of resurgent English (rather than British) populism.

In the second contribution, Zappettini (2019b) investigates the discourses of the two organisations designated by the UK Electoral Commission as the official lead campaigns for the 'leave' and 'remain' vote, focusing on the institutional framing of the referendum debate and on the structural conditions that allowed for the emergence and legitimization of the in/out camps. For Zappettini, the discursive opportunities created by the institutional framework effectively enabled these two actors to fill the 'Brexit' signifier with specific and selected signifieds and to simplistically associate such meanings with the contingency of the in/out referendum binary. From this perspective, his analysis provides evidence of the key themes that gained traction in the public arena, namely trade and immigration. As Zappettini argues, despite adopting different argumentative positions, the two actors largely framed the Brexit debate within representations of the Single Market and of Europe as a zero-sum trading exercise whilst civic and transnational discourses of European solidarity were notably absent. In the case of Vote Leave, the 'moral panic' constructed around immigration proved a key narrative - albeit premised on fallacies and misrepresentations - which, Zappettini suggests, ultimately has legitimised Brexit along a toxic logic of new mercantilism, nationcentric imaginaries and rejec- tion of the 'other'.

Tolson's (2019) contribution adopts the perspective of journalistic practices to highlight how anonymous vox pops featuring in TV reports during and after the referendum campaign became highly newsworthy 'soundbites' that contributed to the legitimation of Brexit as a choice of/for the people. More importantly, for Tolson, by reproducing stereo- typical representation of 'ordinary' voters, the media had a pivotal role in the construction of Brexit as a populist scenario. As Tolson critically suggests, the news agenda that drove Brexit fed specific narratives of division, for example by representing social and cultural distances between the disengaged Leavers in rural and industrial Britain on one side and the Westminster-based metropolitan elites of politicians and journalists on the other. Tolson argues that eventually the journalistic use of vox pops contributed to a con- vergence between such populist discourses and a normalisation of their reproduction in the public sphere.

A similar reading of Brexit from populist and public sphere perspectives is offered by Ruzza and Pejovic (2019) who analyze the cultural frames that most frequently characterised interpretations of Brexit in Facebook posts addressed to the EU Commission and the European Parliament immediately after the referendum. Likening this virtual context of production of discourses to a transnational arena of debate where mobilisation around Brexit arises similarly to social movement dynamics, Ruzza and Pejovic's analysis interprets Brexit as part of an emerging (panEuropean) populist ideology that pits the 'elite' against 'the people'. In this case, the 
authors suggest that in Facebook posts, the frame of 'the EU elites as culprits' was frequently underpinning the logic of Brexit, with different categories of actors - such as national politicians, financial institutions and multinational corporations conveniently conflated with the EU institutions and juxtaposed with 'ordinary people'. Similarly, democratic deficit and the understanding of Brexit as a restoration of British freedom were powerful discursive drivers for Leavers. Ruzza and Pejovic suggest that while frames referring to the legitimacy of supranational governance were prevalent in the posts, discourses of migration and the economy (the key arguments of the official Leave/Remain campaigns) were relatively less significant in the dataset analyzed. Another point raised by Ruzza and Pejovic is that whilst the transnational space of debate was open to everyone, the majority of active participants were (pro-Brexit) British. As the authors suggest, this may indicate the historic British insular attitudes may in fact have been traded off for the political opportunity of a new ideological anti-cosmopolitan coalition coalesced around the Brexit vote.

In the following contribution, Bennett (2019) contends that the narration of crisis was pivotal in the Brexit campaign. Focusing on a televised debate broadcast by the $B B C$ close to the referendum date, Bennett traces frames and linguistic features deployed by cross- party representative of the two coalitions trying to persuade 'floating' voters. Bennett's key argument is that the vote over Brexit was discursively positioned as a 'turning point' in what was narrated by both Leave and Remain sides as a crisis. In the author's analysis, for Leavers the crisis was already present and the solution they envisaged was to leave the EU and thereby remove the threats/problems associated with it (exemplified by the topos of taking control). Conversely, for Remainers the crisis would in fact be triggered by the choice of leaving the EU. Bennett suggests that both sides invoked general crisis scenarios which, in turn, recontextualised discourses of other crises, namely immigration, sovereignty, economy and public services. Significantly, Bennett highlights how, while dis- courses articulated in the televised debate were polarised around the remain/leave split, they cut across different political affiliations in a temporary suspension of traditional partisan alignment.

Finally, Krzyżanowski (2019) offers further evidence of how different representations of crises (whether real or imagined) sustained the framing of Brexit in/by the international press. In a comparative study covering four European countries with different levels of engagement with the European project (Austria, Germany, Poland and Sweden), Krzyżanowski shows how both the liberal and conservative press of these countries, unlike most of the British press, represented Brexit as both a current and a future 'real' crisis placing different emphasis on its social, political and economic implications. However, while his analysis suggests a convergence of discourses towards an international and a European (public sphere) reading of Brexit, Krzyżanowski also highlights the significant degree of domestication of news of Brexit across the four national dimensions especially in relation to neoliberally-framed economic and Eurosceptic discourses that clearly gained increased traction even in the seemingly proEuropean liberal and conservative media. 


\section{Tracing the discursive trajectories of Brexit. A critical discourse studies agenda for future analysis}

Although the Brexit juncture is still in the making, the contributions in this issue have highlighted some overarching themes and pointed to how Brexit has been discursively consolidating around a number of intersecting ideologically-anchored trajectories.

The first emergent trajectory encompasses a large proportion of discourses driven by populist and nationalist ideologies. As we have shown, the Brexit debate was typically framed in antagonistic terms, whether through representations of 'us' and 'them', 'cosmopolitan' vs. 'rural', 'ordinary people' vs. the 'elite', 'Europe' vs. 'Britain' and so on (see contributions by Tolson, 2019; Ruzza \& Pejovic, 2019). Of course, the resurgence of populist and nationalist discourses is not simply a Brexit-specific or a uniquely British phenomenon but a multi-faceted one that has wider European and worldwide dimensions (see for example Krzyżanowski, 2018; Krzyżanowski, Triandafyllidou, \& Wodak, 2018; Wodak \& Krzy- żanowski, 2017). This calls for an examination of cross-national as well as localised forms of such discursive trajectories and their interplay with the unfolding of Brexit. For example, we have seen how many discursive manifestations of Brexit encapsulated an ideological shift from a political, economic and cultural order of supranational and multilateral relations to a world order based on national independence and neoliberal intergovernmentalism, a reverse of Fukuyama's (2006) prediction on the 'end of history'. It will be important to follow how these discourses play out in relation to future choices of the British government over the new relationship with the EU and other countries, which future trade and social policies will be adopted after Brexit and what their impact will be. It will be equally important to continue investigating the patterns of populist and nationalist legitimation of Brexit in a wider sense (see also below) along with the surely still forthcoming further attempts to package the national 'wilful self-harm' (O'Toole, 2018) as it is in discourses of postimperialist success and grandeur.

The second discursive trajectory that we bring attention to is that of political crisis. Not only has the notion of crisis (both external and internal to the UK) represented a powerful anchor around which many discourses of Brexit unfolded during the referendum in the UK and internationally (see articles by Bennett, 2019; Krzyżanowski, 2019) but ideological struggles around such discourses have also contributed to major changes in the British political landscape. In this respect, while the Brexit vote notably tallied with working class voters drifting away from traditional Labour links and towards the Conservative party and UKIP, the ideological Leave/Remain split has now transcended the traditional left/right divide in British politics (see Bennett, 2019). Moreover, ideological struggles over the execution of Brexit have precipitated the UK and its constituent countries into a constitutional crisis over the power of Parliament, the function of democracy, and the remits of national and regional sovereignty which is likely to have profound repercussions in the short and long term. 
The third discursive trajectory that will require close examination is the process of legitimation of Brexit. As we have shown, the referendum was part of a discursive chain through which discourses that had emerged on the fringe of politics (but historically rooted) gradu- ally climbed up the institutional chain to become normalised into the language of government. This process has been sustained by different discursive tools, for example the tautology of 'Brexit means Brexit' and the rhetorical appeal to the 'will/voice of the people'. The latter, in particular, has become a key discursive driver and an ambivalent signifier of democratic and populist chains of legitimation and pre-legitimation (Krzyżanowski, 2014) that are defining the struggle around the 'privileged sign' of Brexit, especially as the 'will of the people' is being discursively retrofitted to the promises of the referendum campaign, thus gaining legitimacy not only by its moral virtue but also specific path-dependency (Leeuwen, 2007). But, as we show, the legitimation of Brexit has also been fuelled by various discursive shifts (Krzyżanowski, 2018) at the institutional level and in public discourses. For example, the UK Government has shifted from an initial position of no compromise with the EU ('no deal is better than a bad deal') to that of cooperation ('a deep and special partnership') and while themes of immigration were prominent during the campaign, the current public debate seems to be more focused on future trade arrangements as the 'bottom line' logic of Brexit.

In taking into account all these discursive dynamics, one can hardly underestimate the role of media in (re)producing and framing such discourses as well as creating wider path- dependencies eventually followed by the wider social and political discourse. Whether it be traditional or new forms of communication (e.g. traditional press, televised debates, online campaigns or Facebook posts), our contributors have provided ample evidence of how Brexit has been a mediated and multi-actor process.

Crucially, Brexit is yet an unfinished process. At the time of writing many uncertainties are still surrounding the so called 'end state' of Brexit, including the final shape of the trade relationship between Britain and the EU, the status of EU citizens in Britain and that of British citizens in the EU as well as the thorny issue of the Irish border, or indeed whether Brexit will occur at all. The plethora of discourses through which these issues are being (re)articulated and (de)legitimised represents a vantage point for any scholar who aims to make sense of Brexit by providing insightful and robust analysis. In keeping with the Critical Discourse Studies orientation of discourse as 'text in context', in this issue we have argued for and provided empirical application of an examination of Brexit as a critical juncture in the making occurring at the intersection of historical, political and mediated dimensions. We encourage future research that will systematically explore both the micro discursive sites where discourses of Brexit are produced and consumed by different actors- e.g. media, government, civil society -and the path dependency trajectories that such discourses create and feed on. 


\section{Notes on contributors}

Franco Zappettini is a Lecturer in Communication and Media at the University of Liverpool where he leads the module on Language and Media. His research focuses on the textual/discursive analysis of different forms of political and organisational communication including mediated forms of populism, such as tabloid populism and Euroscepticism in the British press. He has published internationally in peer-reviewed journals. His latest publication is the monograph 'European identities in Discourse: A transnational citizens' perspective' Bloomsbury (2019).

Michał Krzyżanowski holds a Chair in Media and Communication Studies at Örebro University, Sweden as well as a research appointment as a Chair in Communication \& Media at the University of Liverpool, UK. In 2018-19 he is also Albert Bonnier Jr. Guest Professor in Media Studies at the Department of Journalism, Media \& Communication, Stockholm University, Sweden. He is one of the leading international experts in critical discourse studies of media and political communication. His key research interests are in dynamics of right-wing populist discourse, normalisation of racism and politics of exclusion as well as in diachronic analyses of politicisation and mediation of crisis in European and transnational media. He is the Editor-inChief of the Journal of Language and Politics and a co-editor of the Bloomsbury Advances in Critical Discourse Studies book series. More infor- mation: https://www.oru.se/english/employee/michal_krzyzanowski and https://www.liverpool.ac. uk/communication-and-media/staff/michal-krzyzanowski. 


\section{References}

Bennett, S. (2019). Present tense, future (im)perfect: 'Brexit' as a crisis issue in UK political discourse. Critical Discourse Studies, in press.

Berlin, I. (1974). Historic inevitability. In P. Gardiner (Ed.), The philosophy of history (pp. 161186).Oxford: Oxford University Press.

Calhoun, C. (2017). Populism, nationalism and Brexit. In W. Outhwaite (Ed.), Brexit: Sociological responses (pp. 57-76). London; New York: Anthem Press.

Capoccia, G. (2016). Critical junctures. In O. Fioretos, T. Falleti, \& A. Sheingate (Eds.), The Oxford hand- book of historical institutionalism (pp. 89-106). Oxford: Oxford University Press.

Capoccia, G., \& Kelemen, D. (2007). The study of critical junctures: Theory, narrative, and counterfac- tuals in historical institutionalism. World Politics, 59(3), 341-369.

Clarke, J., \& Newman, J. (2017) 'People in this country have had enough of experts': Brexit and the paradoxes of populism. Critical Policy Studies, 11(1), 101-116.

Evans, G., \& Menon, A. (2017). Brexit and British politics. London: Polity Press.

Fukuyama, F. (2006). The end of history and the last man. New York: Free Press, Simon and Schuster. Koller, V., Kopf, S., \& Miglbauer, M. (Eds.). (2019). Discourses of Brexit. London:

Routledge.

Koselleck, R. (1979). Critique and crisis. Cambridge, MA: MIT Press.

Koselleck, R. (2004). Futures past: On the semantics of historical time. New York, NY: Columbia University Press.

Krzyżanowski, M. (2010). The discursive construction of European identities. Frankfurt: Peter Lang. Krzyżanowski, M. (2014). Values, imaginaries and templates of journalistic practice: A critical discourse analysis. Social Semiotics, 24(3), 345-365.

Krzyżanowski, M. (2018). Discursive shifts in ethno-nationalist politics: On politicization and mediati- zation of the "refugee crisis" in Poland. Journal of Immigrant \& Refugee Studies, 16(1-2), 76-96.

Krzyżanowski, M. (2019). Brexit and the imaginary of 'crisis': A discourse-conceptual analysis of European news media. Critical Discourse Studies, in press.

Krzyżanowski, M., Triandafyllidou, A., \& Wodak, R. (Eds.). (2018). The mediatization and politicization of the refugee crisis in Europe. Journal of Immigrant and Refugee Studies, 16, 1-14. London: Routledge.

Leeuwen, T. V. (2007). Legitimation in discourse and communication. Discourse \& Communication, 1 (1), 91-112. doi:10.1177/1750481307071986

Maccaferri, M. (2019). Splendid isolation again? Brexit and the role of the press and online media in re-narrating the European discourse. Critical Discourse Studies, in press.

O'Toole, F. (2018). Heroic failure: Brexit and the politics of pain. London: Head of

Zeus. Outhwaite, W. (2017). Brexit: Sociological responses. London: Anthem Press.

Ridge-Newman, A., Leon-Solis, F., \& O'Donnell, H. (Eds.). (2018). Reporting the road to Brexit. Basingstoke: Palgrave Macmillan.

Ruzza, C., \& Pejovic, M. (2019). 'Populism at work: The language of the Brexiteers and the European Union'. Critical Discourse Studies, in press.

Tolson, A. (2019). "Out is out and that's it the people have spoken": Uses of vox pops in UK TV news coverage of the Brexit referendum. Critical Discourse Studies, in press.

Wincott, D., Peterson, J., \& Convery, A. (2017). Introduction: Studying Brexit's causes and consequences. The British Journal of Politics and International Relations, 19(3), 429-433.

Wodak, R., \& Krzyżanowski, M. (Eds.). (2017). Right-wing populism in Europe and the USA: Contesting politics and discourse beyond 'orbanism' and 'trumpism'. Journal of Language and Politics, 16, 471- 484. 
Zappettini, F. (2019a). The official vision for 'global Britain': Brexit as rupture and continuity between free trade, liberal internationalism and 'values'. In V. Koller, S. Kopf, \& M. Milgbauer (Eds.), Discourses of Brexit (pp. 140-154). Abingdon: Routledge.

Zappettini, F. (2019b). The Brexit referendum: How trade and immigration in the discourses of the official campaigns have legitimised a toxic (inter)national logic. Critical Discourse Studies, in press. 